\title{
PENGARUH GAYA DAN MOTIVASI BELAJAR TERHADAP KEMAMPUAN PENALARAN MATEMATIS
}

\author{
Deviana Sumartiningsih, Lisma Dian K. Sari \\ STKIP PGRI Situbondo \\ dhepiana08@gmail.com
}

\begin{abstract}
Abstrak: Dalam proses belajar mengajar, salah satu kunci keberhasilan siswa adalah menggunakan gaya belajar yang sesuai agar mampumenyerap, mengatur, dan mengolah informasi yang diterima. Faktor lainnya adalah motivasi belajar sebagai pendorong siswa untuk meraih sebuah prestasi. Penelitian ini bertujuan untuk mengetahui apakah ada pengaruh gaya belajar dan motivasi belajar terhadap kemampuan penalaran matematis siswa pada mata pelajaran matematika. Penelitian kuantitatif ini dilakukan dengan jumlah sampel sebanyak 100 siswa menggunakan teknik Simple Random Sampling. Metode pengumpulan data menggunakan angket dan tes.Teknik analisis data yang digunakan adalah analisis regresi berganda, dan untuk uji hipotesis menggunakan korelasi ganda. Hasil penelitian menunjukkan bahwa terdapat pengaruh yang signifikan antara gaya belajar dan motivasi belajar terhadap kemampuan penalaran matematis siswa. Diperoleh persamaan regresi $Y=76,868-0,261 x_{1}+0,348 x_{2}$ dengan kontribusi sumbangan efektifitas garis regresi sebesar 6,67\%. Dari hasil uji F dan korelasi ganda diperoleh $F_{\text {hitung }}$ sebesar 3,4661 dan $R_{\text {hitung }}$ sebesar 0,2584. Diperoleh $F_{\text {reg }}$ lebih besar dari $\mathrm{F}_{\mathrm{tab}}$ ini menunjukkan bahwa hipotesis diterima.
\end{abstract}

Kata kunci: gaya belajar, motivasi belajar, kemampuan penalaran matematis

\begin{abstract}
In the teaching and learning process, one of the keys to the success of students is to use appropriate learning styles in order to be able to absorb, organize, and process the information received. Another factor is motivation to learn as an encouragement for students to achieve an achievement.This study aims to determine whether there is an influence of learning styles and learning motivation on students' mathematical reasoning abilities on mathematics subjects. This quantitative research was conducted with a total sample of 100 students using the Simple Random Sampling Technique. Methods of data collection using questionnaires and tests. The data analysis technique used is multiple regression analysis, and for hypothesis testing using multiple correlation. The results showed that there was a significant effect between learning styles and learning motivation on students' mathematical reasoning abilities. Regression equation obtained $\mathrm{Y}=$ $76,868-0,261 \mathrm{X}_{1}+0,348 \mathrm{X}_{2}$ with the contribution of the regression line effectiveness contribution of $6,67 \%$. From the results of the $\mathrm{F}$ test and multiple correlations obtained $F_{\text {reg }}$ of 3.4661 and $R_{\text {count }}$ of 0.2584 . $F_{\text {reg }}$ obtained greater than $\mathrm{F}_{\text {tab }}$ shows that the hypothesis is accepted.
\end{abstract}

Keywords: learning styles, learning motivation, mathematical reasoning ability 


\section{PENDAHULUAN}

Matematika merupakan mata pelajaran yang menjadi tonggak kemajuan ilmu pengetahuan dan teknologi. Depdiknas 2006 (dalam Purnamasari, 2014) menyatakan bahwa "Untuk menguasai dan menciptakan teknologi di masa depan diperlukan penguasaan matematika yang kuat sejak dini". Menurut Wahyudin (dalam Sumartini, 2015) menemukan bahwa salah satu kecenderungan yang menyebabkan siswa gagal menguasai dengan baik pokok-pokok bahasan dalam matematika yaitu siswa kurang memahami dan menggunakan nalar yang baik dalam menyelesaikan soal yang diberikan. Namun dua individu yang tumbuh dalam lingkungan yang sama, mendapat perlakuan yang sama belum tentu akan memiliki pemahaman, pemikiran, dan pandangan yang sama terhadap dunia sekitarnya. Masing-masing memiliki cara pandang sendiri terhadap setiap peristiwa yang dilihat dan dialaminya, cara pandang inilah yang dikenal dengan gaya belajar.

De Porter dan Hernacki (dalam Indarto, 2012:20) mengemukakan secara umum gaya belajar terbagi menjadi tiga, yang biasa dikenal dengan VAK(Visual, Auditorial, dan Kinestetik).Dengan demikian siswa harus mempunyai keinginan, dorongan yang kuat untuk belajar dan mendapatkan apa yang menjadi tujuan mereka didalam proses pembelajaran matematika sesuai dengan kenyamanan cara mereka belajar. Faktor internal lain yang memberikan pengaruh positif terhadap proses pembelajaran adalah adanya motivasi belajar dari siswa. Menurut Clelland (dalam Surya, 2014:57) pada dasarnya dalam diri setiap orang terdapat kebutuhan untuk melakukan perbuatan dalam memperoleh hasil yang sebaik-baiknya, kebutuhan ini disebut sebagai kebutuhan untuk berprestasi (need for achievement). Motivasi belajar memiliki peranan yang sangat besar dengan usaha yang terus menerus untuk meraih prestasi. Motivasi dalam hubungannya dengan pembelajaran, merupakan suatu dorongan, keinginan, maupun kebutuhan peserta didik yang diwujudkan dalam bentuk usaha untuk mencapai atau memperoleh prestasi belajar yang setinggi-tingginya (Surur \& Tartilla 2019).

Dalam hal ini, hasil dan prestasi yang diharapkan adalah kemampuan penalaran matematis dalam proses berpikir untuk mencapai satu kesimpulan yang logis pada gagasan objek dan pernyataan matematika. Oleh karena itu untuk mendapatkan kemampuan penalaran matematis yang baik dan maksimal diperlukan gaya belajar siswa dan motivasi belajar yang tepat serta mendukung dalam proses pembelajaran matematika. Berdasarkan masalah di atas, maka peneliti tertarik untuk melakukan penelitian tentang "Pengaruh Gaya Belajar dan Motivasi belajarTerhadap Kemampuan Penalaran Matematis".

\section{METODE}

Dalam penelitian ini menggunakan pendekatan kuantitatif dan metode rancangan penelitian yang digunakan adalah Ex Post Facto, yaitu penyelidikan yang direncanakan dan dilakukan secara sistematis dalam bentuk yang nyata terhadap variabel terikat terhadap variabel bebas.Teknik penentuan lokasi penelitian adalah Purposive Sampling Area.Metode purposive adalah merupakan metode penentuan daerah penelitian yang sengaja dan berdasarkan ciri-ciri sifat populasi yang sudah 
EDUSAINTEK: Jurnal Pendidikan Sains dan Teknologi

VOLUME 6. No. 1 Mei 2019

ISSN: $1858-005 \mathrm{X}$ diketahui sebelumnya (Hadi, 2001:82).Sampel yang digunakan dalam penelitian ini adalah Simple Random Sampling, dikatakan Simple (sederhana) karena 
pengambilan anggota sampel dari populasi dilakukan secara acak tanpa memperhatikan strata yang ada dalam populasi itu.

Teknik pengumpulan data menggunakan metode angket dan tes. Pada metode angket digunakan jenis angket tertutup, dan skala pengukuran untuk alternatif jawaban yang ditawarkan pada responden peneliti menggunakan skala Likert dengan empat interval. Yaitu "Sangat Setuju", "Setuju", "Kurang Setuju", dan "Tidak Setuju". Tujuan penyebaran angket ialah mencari informasi dan memperoleh data tentang gaya belajar dan motivasi belajar siswa. Sedangkan pada metode tes, peneliti menggunakan tes tertulis bentuk uraian (essay) yang diambil dari soal ujian Nasional (UN). Karena tes dalam bentuk ini dapat memunculkan kreativitas siswa dalam berpikir dan menyusun jawaban sesuai dengan pendapat dan pemikiran mereka sendiri.

Setelah melakukan penelitian dan data terkumpul dilakukan langkah awal yaitu Skoring, Coding, dan Tabulasi. Kemudian data yang telah diolah dapat kita analisis prasyarat menggunakan uji validitas dan uji reliabilitas untuk mengetahui data itu sudah benar dan sesuai.Teknik analisis data digunakan untukmencari kebenaran dan membukti-kan hipotesis yang diajukan. Peneliti menggunakan teknik analisis statistik sebagai berikut (Sugiyono, 2014):

1. Analisis Regresi Berganda

2. Menghitung Korelasi

3. Menghitung Analisis Varian Garis Regresi $\left(\mathrm{F}_{\mathrm{reg}}\right)$

4. Efektifitas Garis Regresi

5. Sumbangan Efektif (SE)

\section{HASIL DAN PEMBAHASAN \\ Hasil}

Untuk memperoleh data dari sejumlah responden,sampel diambil dari siswa kelas X IPA di MA Negeri 2 Situbondo, Digunakan model angket yang disebarkan kepada responden, untuk pengumpulan data penelitian diperlukan data sebagai berikut:

1. Data tentang gaya belajar dan motivasi belajar

2. Data tentang hasil kemampuan penalaran matematis siswa

Angket tersebut terdiri dari 30 item yang terbagi menjadi 2 bagian yaitu:

1. Bagian I nomor $1-15$ item pertanyaan tentang gaya belajar $\left(\mathrm{X}_{1}\right)$.

2. Bagian II nomor 16 - 30 item pertanyaan tentang motivasi belajar $\left(\mathrm{X}_{2}\right)$

Dan data hasil kemampuan penalaran matematis siswa diperoleh dari tes yang diberikan kepada siswa dalam bentuk uraian (essay).

Data hasil angket yang berupa data kuantitatif tersebut kemudian diolah menggunakan program Microsoft Excel, hitung manualdan SPSS for Windows release 17.0.Dari hasil skoring dan tabulasi dapat diketahui hasil dan keadaan siswa dalam hal gaya belajar,serta motivasi belajarberikut ini: 
1. Gaya Belajar

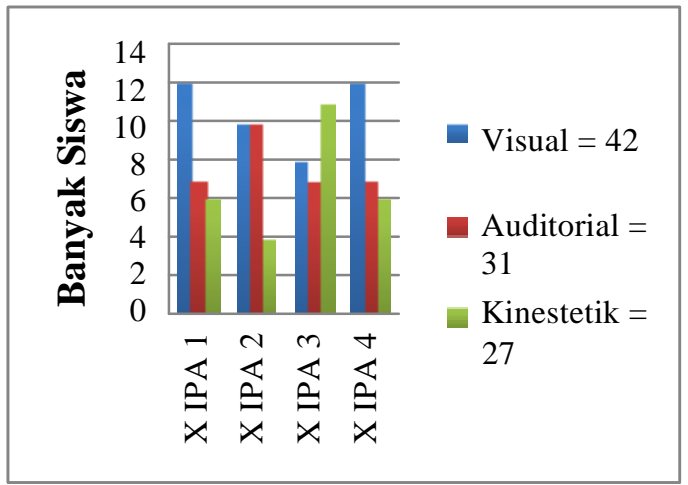

2. Motivasi belajar

Gambar 1.Gaya Belajar Siswa

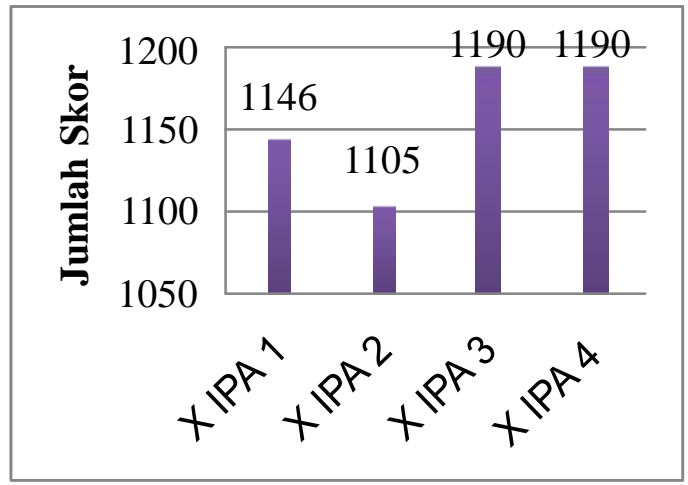

Gambar 2.Motivasi belajar Siswa

Motivasi belajar dikatakan sangat tinggi (100\%) jika jumlah yang diperoleh adalah 6000, jumlah skor kriterium $=4$ × $15 \times 100=6000$.

Dengan rincian:

Skor tertinggi tiap butir $=4$

Jumlah butir $\quad=15$

Jumlah responden $\quad=100$

Dari hasil perhitungan data penelitiantentang motivasi belajar diperoleh jumlah skor $=4631$, dengan demikian diperoleh besar persentase

$\frac{4631}{6000} \times 100 \%=77,18 \%$ atau $77 \%$

Hal ini secara kontinum dapat dibuat kategori sebagai berikut:

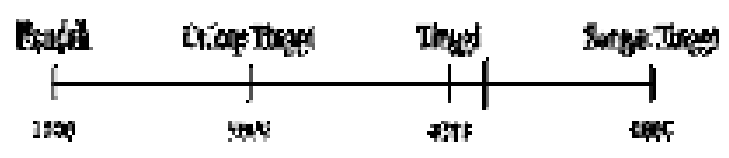


Nilai 4631 termasuk dalam kategori interval "Tinggi dan Sangat Tinggi", tetapi lebih mendekati Tinggi.Sehingga siswa memiliki motivasi belajar yang tinggi.

3. Kemampuan Penalaran Matematis

Datadiolah sedemikian hingga diperoleh bentuk Tabel 1dengan menyertakan mean, modus, dan median.

Tabel 1.DistribusiFrekuensiDataKemampuanPenalaran Matematis

\begin{tabular}{|c|c|c|c|}
\hline $\begin{array}{l}\text { Kelas } \\
\text { Ke }\end{array}$ & \multicolumn{2}{|c|}{ NilaiTes BatasKelas } & rekuensi \\
\hline 1 & $70-73$ & $69,5-73,5$ & 7 \\
\hline 2 & $74-77$ & $73,5-77,5$ & 17 \\
\hline 3 & $78-81$ & $77,5-81,5$ & 41 \\
\hline 4 & $82-85$ & $81,5-85,5$ & 4 \\
\hline 5 & $86-89$ & $85,5-89,5$ & 18 \\
\hline 6 & $90-93$ & $89,5-93,5$ & 3 \\
\hline 7 & $94-97$ & $93,5-97,5$ & 8 \\
\hline 8 & $98-101$ & $97,5-101,5$ & 2 \\
\hline Total & 8.192 & 8.192 & 100 \\
\hline Mean & & 81,9 & \\
\hline Modus & & 80 & \\
\hline Median & & 80 & \\
\hline
\end{tabular}

\section{Pembahasan}

Penelitian dilakukan untuk mengetahui ada tidaknya pengaruh antara gaya belajar dan motivasi belajar terhadap kemampuan penalaran matematis siswa kelas X IPA di MA Negeri 2 Situbondo. Pengumpulan data dilakukan dengan menyebarkan angket dan tes (essay) kepada siswa.Hasil angke di skoring dan ditabulasi sehingga dapat diketahui hasil dan keadaan siswa dalam hal gaya belajar, motivasi belajar dan kemampuan penalaran matematis yang dimiliki.

Sebelum analisis data dilakukan uji validitas dan reliabilitas untuk mengetahui kebenaran dan kesesuaian instrumen yang digunakan. Dari hasil perhitungan validitas diperoleh $R_{\text {hitung }}>R_{\text {tabel }}$, maka keseluruhan 30 item pada instrumen yang digunakan untuk pengumpulan data dengan penyebaran angket kepada siswa kelas X IPA di MA Negeri 2 Situbondo bernilai valid. Untuk uji reliabilitas menggunakan program SPSS for Windows release 17.0, diperoleh nilai yang melebihi dari $\mathrm{R}_{\text {tabel }}$ sehingga dapat disimpulkan bahwa instrumen yang digunakan sudah sesuai atau reliabel.

Diperoleh persamaan garis regresi berganda adalah $Y=76,868-0,261 x_{1}+0,348 x_{2}$. Hal ini dapat diartikan bahwa kemampuan penalaran matematis (variabel Y) siswa kelas X IPA di MA Negeri 2 Situbondo akan mengalami perubahan sebesar $-0,261$ untuk setiap unit perubahan yang terjadi pada gaya belajar (variabel $\mathrm{X}_{1}$ ), dan juga akan mengalami perubahan 
sebesar 0,348 untuk setiap unit perubahan yang terjadi pada motivasi belajar (variabel $\mathrm{X}_{2}$ ).

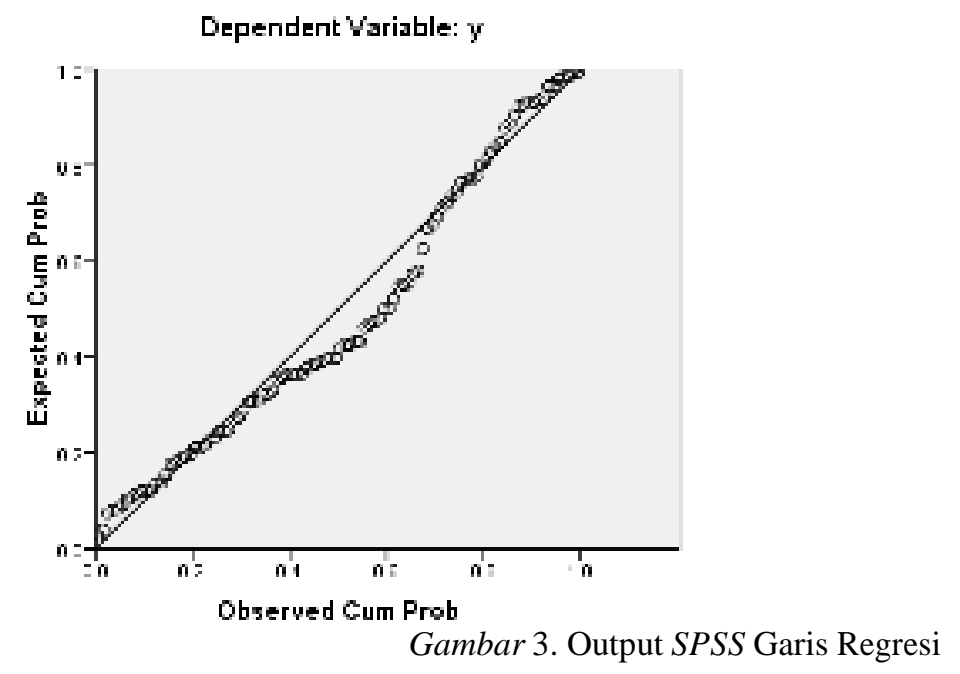

Dari hasil SPSSseperti yang ditunjukkan padaGambar 3 dapat diketahui bahwa, variabel-variabel tersebut mempunyai hubungan yang cukup dekat. Hal ini ditunjukkan oleh titik-titik pada diagram yang terletak saling berdekatan dengan garis yang bisa ditarik melalui titik tersebut.

Dari persamaan garis regresi yang diperolehnilai $\mathrm{X}_{1}$ yaitu gaya belajar memiliki pengaruh, namun berbanding terbalik. Yang artinya Y mempengaruhi $\mathrm{X}_{1}$ yang artinya kemampuan penalaran matematis siswa yang mempengaruhi gaya belajar siswa tersebut. Hal ini dapat terjadi karena pada pengisian angket responden terkadang mengisi pernyataan yang diajukan secara acak (sembarang). Hal ini juga tidak sesuai dengan kajian empiris yang mengatakan bahwa gaya belajar mempengaruhi prestasi belajar matematika (dalam Ramlah dkk, 2014).

Dalam penelitian ini besar pengaruh gaya belajar terhadap kemampuan penalaran matematis siswa kelas X IPA di MA Negeri 2 Situbondo, adalah 0,261. Ini sesuai dengan kondisi yang ada di lapangan (sekolah) yaitugaya belajar yang dimiliki masing-masing siswa dalam proses pembelajaran matematika kurang berperan penting untuk menghasilkan kemampuan penalaran matematis yang baik. Karena kenyataannya pada setiap proses pembelajaran, siswa belajar sesuai dengan metode atau cara yang guru ajarkan, sehingga gaya belajar yang dimiliki masing-masing siswa tidak berpengaruhterhadap prestasi belajar siswa. Kategorisasi gaya belajar yang tinggi pada siswa MA Negeri 2 Situbondo adalah gaya belajar visual dan auditorial.

Dari persamaan garis regresi yang diperoleh untuk nilai $\mathrm{X}_{2}$ yaitu motivasi belajar yang memiliki pengaruh cukupsignifikan terhadap kemampuan penalaran matematis siswa kelas X IPA di MA Negeri 2 Situbondo. Ini dapat dilihat dari hasil perhitungan sebesar 0,348. Hal ini dapat diartikan bahwa motivasi belajar yang dimiiki oleh siswa berpengaruh terhadap kemampuan penalaran matematis yang dimilikinya, namunmasih cukup rendah. Oleh sebab itu siswa dengan 
bantuan motivasi dari guru dapat meningkatkan motivasi belajar siswa untuk mencapai prestasi yang lebih tinggi lagi. Pernyataan ini tentu sesuai dengan kajian empiris, yaitu semakin baik motivasi berpretasi yang dimiliki oleh siswa maka semakin baik pula kemampuan penalaran matematisnya.Hal ini juga sejalan dengan apa yang dikemukakan oleh Surya, motivasi belajar adalah perbuatan yang dilakukan oleh seseorang itu didorong oleh adanya kebutuhan untuk berprestasi sebaik mungkin dalam mencapai tujuan.

Dari hasil analisis data menggunakan korelasi parsial dan korelasi ganda untuk mencari nilai efektifitas garis regresi diperoleh hasil sebesar 6,67\%. Ini menunjukkan bahwa sumbangan efektifitas gaya belajar dan motivasi belajar terhadap kemampuan penalaran matematis siswa kelas X IPA di MA Negeri 2 Situbondo sebesar $6,67 \%$.

Sumbangan variabel bebas $(\mathrm{X})$ terhadap variabel terikat $(\mathrm{Y})$ dari keseluruhan variabel yang ada (tanpa adanya faktor lain) yaitu gaya belajar $\left(X_{1}\right)$ sebesar $1,47 \%$ dan motivasi belajar $\left(X_{2}\right)$ sebesar 5,20\%.Sedangkan sumbangan variabel bebas $(\mathrm{X})$ terhadap variabel terikat $(\mathrm{Y})$ apabila terdapat variabel lain selain variabel bebas (X)besar sumbangannya yaitu sebesar 93,33\%.

Dari hasil uji $\mathrm{F}$ diketahui besar $\mathrm{F}_{\text {hitung }}$ adalah 3,4661, ini lebih besar dari $\mathrm{F}_{\text {tabel }}$ yaitu 3,0901 pada $\mathrm{N}=100$.Ini menunjukkan bahwa hipotesis kerja mayor akan terbukti karena $F_{\text {hitung }}$ lebih besar dari $F_{\text {tabel }}$ dengan taraf signifikan 5\%. Dan dari hasil perhitungan korelasi diperoleh $\mathrm{R}_{\text {hitung }}$ lebih besar dari $\mathrm{R}_{\text {tabel }}$ yaitu sebesar 0,2584dari $\mathbf{R}_{\text {tabel }}$ yaitu 0.195yang dibandingkan dengan tabel interpretasi korelasi.

Dengan demikianhipotesis nihil (Ho) ditolak dan hipotesis kerja (Ha) diterima, sehingga dapat disimpulkan bahwa "Terdapat pengaruh positif gaya belajar dan motivasi belajar terhadap kemampuan penalaran matematis siswa pada mata pelajaran matematika kelas X IPA semester genap di MA Negeri 2 Situbondo tahun pelajaran 2017/2018”.

\section{PENUTUP}

Terdapat pengaruh sebesar $1,47 \%$ antara gaya belajar terhadap kemampuan penalaran matematis, dan terdapat pengaruh sebesar 5,20\% antara motivasi belajar terhadap kemampuan penalaran matematis. Sedangkan pengaruh sebesar $6,67 \%$ diperoleh dari konstribusi kedua variabel yaitugaya belajar dan motivasi belajar terhadap kemampuan penalaran matematis siswa pada mata pelajaran matematika kelas X IPA semester genap di MA Negeri 2 Situbondo tahun pelajaran $2017 / 2018$.

\section{DAFTAR PUSTAKA}

Hadi, S. 2001. Metodologi Research. Yogyakarta: Andi

Indarto, I. 2012. "Pengaruh Gaya Belajar dan Motivasi belajar Siswa Terhadap Prestasi Belajar Praktik Instalasi Listrik di Smk Negeri 2 Yogyakarta”.Skripsi Fakultas Teknik, Universitas Negeri Yogyakarta. Purnamasari, Y. 2014. "Pengaruh Model Pembelajaran Kooperatif Tipe Teams Games Tournament (Tgt) Terhadap Kemandirian Belajar dan 
PeningkatanKemampuan Penalaran dan Koneksi Matematik Peserta Didik SMPN 1 Kota Tasikmalaya", Jurnal Pendidikan dan Keguruan.Vol. 1 No. 1.pp. 2.

Ramlah, Firmansyah, D. dan Zubair, H. 2014. "Pengaruh Gaya Belajar dan Keaktifan Siswa Terhadap Prestasi Belajar Matematika", Jurnal Ilmiah Solusi.Vol. 1 No. 3. pp. 68-75.

Sugiyono. 2013. Metode Penelitian PendidikanPendekatan Kuantitatif, Kualitatif dan $R \& D$. Bandung: Alfabeta.

Sumartini, T. 2015. "Peningkatan Kemampuan Penalaran Matematis Siswa Melalui Pembelajaran Berbasis Masalah”, Jurnal Pendidikan Matematika. Vol. 5 No. 1.pp. 1.

Surur, M., \& Tartilla, T. Pengaruh Problem Based Learning dan Motivasi Berprestasi terhadap Kemampuan Pemecahan Masalah. Indonesian Journal of Learning Education and Counseling, 1(2), 169-176.

Surya, M. 2014. Psikologi Guru Konsep dan Aplikasi. Bandung: Alfabeta. 